\title{
PEMANFAATAN LAHAN BEKAS GALIAN BATU BATA MENJADI EMPANG IKAN AIR TAWAR
}

\author{
Afif Hakim \\ Teknik Industri, Fakultas Teknik dan Ilmu Komputer \\ Universitas Buana Perjuangan Karawang \\ Afif.hakim@ubpkarawang.ac.id
}

\begin{abstract}
Abstrak
Desa Mekarmulya adalah salah satu desa dari 10 desa yang masuk dalam wilayah administratif Kecamatan Telukjambe Barat, Kabupaten Karawang. Dikepalai oleh seorang kepada desa dan dibantu oleh seorang sekretaris desa dan segenap perangkat desa. Desa Mekarmulya dikenal sebagai sentral industri rumahan (home industry) pembuatan batu bata merah pres. Hampir semua warga menjadi pembuat batu bata merah. Namun lambat laun usaha ini kian lesu dan kalah bersaing dengan adanya batu bata ringan. Lesunya penjualan batu bata merah ini juga dirasakan langsung oleh para buruh yang bekerja di salah satu pengrajin batu bata merah. Di sisi lian, terdapat potensi bekas galian material batu bata merah menjadi kolam untuk budi daya ikan air tawar sebagai tambahan penghasilan bagi para pengrajin bata merah yang mulai menurun. Untuk sementara waktu, sebagai permulaan ikan yang direkomendasikan adalah ikan nila karena mudah beradaptasi dengan lingkungan dan cepat berkembang biak. Selain budi daya ikan dan dijual secara mentah, juga disarankan untuk menjual hasil ikan tersebut berupa makanan olahannya seperti nugget, ikan asap, dan lain-lain.
\end{abstract}

Kata kunci: Mekarmulya, Batu Bata Merah, Budidaya, Ikan Air Tawar

\begin{abstract}
Mekarmulya Village is one of the 10 villages included in the administrative area of Telukjambe Barat District, Karawang Regency. Headed by a village officer and assisted by a village secretary and all village officials. Mekarmulya Village is known as the center of the cottage industry for making pressed red bricks. Almost all residents become red brick makers. However, gradually this business became sluggish and could not compete with the light bricks. The sluggish sales of red bricks were also felt directly by the workers who worked in one of the red brick craftsmen. On the other side, there is the potential for the ex-excavated red brick material to become a pond for freshwater fish resources as an additional stage for the red brick craftsmen, which is starting to decline. For a while, the fish that refused to start was tilapia because it was easy to adapt to the environment and quickly reproduced. Apart from cultivating fish and selling it raw, it is also advisable to sell fish products in the form of processed food such as nuggets, smoked fish, and others.
\end{abstract}

Keywords: Mekarmulya, Red Bricks, Cultivation, freshwater fish 


\section{PENDAHULUAN}

Kecamatan Telukjambe Barat adalah salah satu kecamatan yang berada di wilayah administratif Kabupaten Karawang. Dikutip dari laman Pemkab Karawang, bahwa Kecamatan Telukjambe Barat merupakan bagian wilayah dari 30 Kecamatan di Kabupaten Karawang yang terbentuk Tahun 2005 berdasarkan Peraturan Pemerintah Nomor 02 Tahun 2005 tentang Pembentukan Kecamatan pada Daerah Kabupaten Karawang yang diresmikan berdirinya pada tanggal 09 Maret 2005 dan mulai melaksanakan kegiatan Pemerintahan sejak tanggal 09 Maret 2005 (sumber : karawangkab.go.id).

Desa Mekarmulya adalah salah satu desa dari 10 desa yang masuk dalam wilayah administratif Kecamatan Telukjambe Barat, Kabupaten Karawang. Dikepalai oleh seorang kepada desa dan dibantu oleh seorang sekretaris desa dan segenap perangkat desa. Jumlah penduduk Desa Mekarmulya sebanyak 3.916 jiwa yang terdiri dari 1.970 laki-laki dan 1.946 perempuan, dengan jumlah kepala keluarga sebanyak 1.248 jiwa. Jarak Desa Mekarmulya ke pusat Kecamatan Telukjambe Barat kurang lebih 2 km dan ke kota Karawang kurang lebih 10 km.

Kondisi mata pencaharian masyarakat di wilayah Desa Mekarmulya bekerja sebagai pengusaha home industry, petani, buruh tani, peternak, pedagang, karyawan swasta, dan PNS. Desa Mekarmulya dikenal sebagai sentral industri rumahan (home industry) pembuatan batu bata merah pres. Hampir semua warga menjadi pembuat batu bata merah. Sentra usaha ini pernah berjaya 20 tahun silam. Namun lambat laun usaha ini kian lesu dan kalah bersaing dengan adanya batu bata ringan (hebel atau celcon) yang harganya lebih murah. Kondisi ini diperparah ketika musim penghujan, pasalnya proses pengeringan dan pembakaran memakan waktu yang lebih panjang, yang berimbas pada menipisnya keuntungan dari penjualan.

Lesunya penjualan batu bata merah ini juga dirasakan langsung oleh para buruh yang bekerja di salah satu pengrajin batu bata merah pres milik Bapak H. Wadi. Akibat anjloknya penjualan batu bata merah produksi pun dikurangi, sehingga pendapat para pekerja berkurang drastis karena sering diliburkan. Oleh karena itu, diperlukan alternative usaha lain yang dapat memberikan tambahan penghasilan bagi para pengrajin bata merah ini. Hasil observasi awal menunjukkan adanya potensi nilai ekonomis dari lubang-lubang bekas galian tanah untuk 
bahan baku batu bata merah yang belum dimanfaatkan. Hasil diskusi dengan Bapak H. Wadi dan Putranya Kang Umar muncul ide untuk memanfatkan bekas-bekas galian tersebut sebagai tempat budi daya ikan air tawar, sehingga nilai ekonomis yang diharapkan menjadi sumber penghasilan baru bagi pemilik bekas galian dan para pekerja. Ikan air tawar merupakan ikan yang hidup di perairan tawar, seperti sungai dan danau dengan salinitas dari 0,05\% (sumber : food.detik.com).

Dari latar belakang di atas, maka diperlukan kegiatan pelatihan wirausaha budidaya ikan air tawar dengan pemanfaatan bekas galian batu bata di Desa Mekarmulya yang dikemas dalam Program Pengabdian Kepada Masyarakat. Hal ini diharapkan dapat memberikan pemahaman, kemampuan dan semangat berwirausaha kepada masyarakat khususnya para pengraji batu bata sehingga diharapkan dapat menciptakan unit-unit bisnis/usaha baru khususnya dalam hal pemanfaatan bekas-bekas galian batu bata sehingga mampu meningkatkan perekonomian masyarakat Kampung Leuweung Kaung, Desa Mekarmulya, Kecamatan Telukjambe Barat, Kabupaten Karawang. Adapun manfaat kegiatan ini secara rinci adalah sebagai berikut.

a. Bagi Pengrajin Batu Bata

- Mendapatkan pengetahuan dan keterampilan tentang budidaya ikan air tawar, dengan memanfaatkan bekas-bekas galian batu bata.

- Diharapkan mampu memberikan tambahan pendapatan dan keuntungan dari budidaya ikan air tawar ini sebagai pengganti dari usaha batu bata merah yang semakin lesu dipasar karena kalah bersaing dengan bata ringan (hebel atau celcon) yang harganya lebih murah).

b. Bagi Desa

- Untuk jangka panjang, adanya peningkatan perekonomian masyarakat desa dengan munculnya unit-unit usaha/bisnis baru, sekaligus sebagai upaya peningkatan Pendapatan Asli Daerah (PAD) di Kabupaten Karawang.

c. Bagi Dosen dan Mahasiswa

- Dapat melaksanakan salah satu Tri Dharma Perguruan Tinggi yaitu Kegiatan Pengabdian Kepada Masyarakat.

- $\quad$ Bersama-sama dengan masyarakat dalam proses pengembangan potensi diri. 


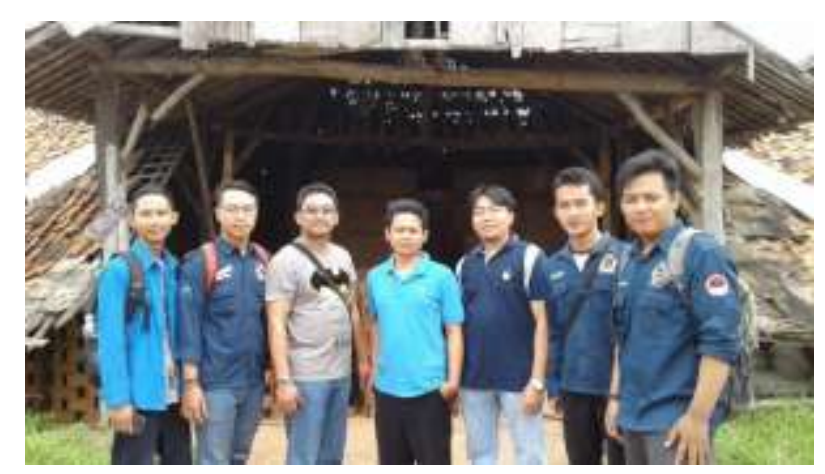

Gambar 1. Home Industry Batu Bata Merah

\section{METODE}

Kegiatan Pengabdian Kepada Masyarakat di Desa Mekarmulya diawali dengan observasi lapangan dan melakukan wawancara langsung dengan sebagian pengrajin bata merah. Kegiatan pelatihan menggandeng Dinas Perikanan dan Kelautan Kabupaten Karawang, dengan memberikan pelatihan budidaya ikan air tawar yang tempatnya akan dilaksanakan di Balai Desa dan kunjungan langsung di bekas galian batu bata milik H. Wadi.

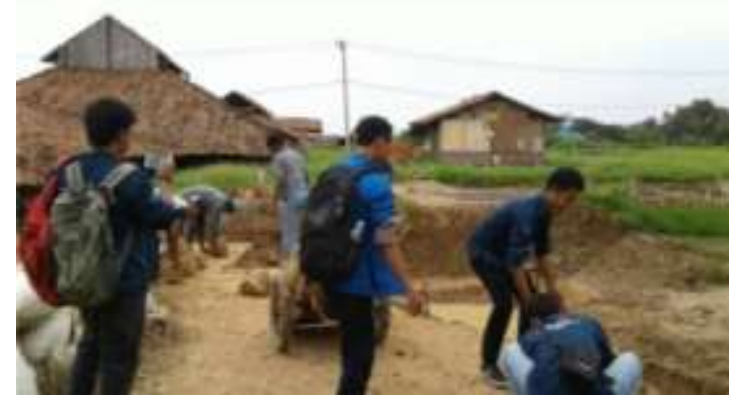

Gambar 2. Lingkungan Kerja Home Industri Batu Bata Merah

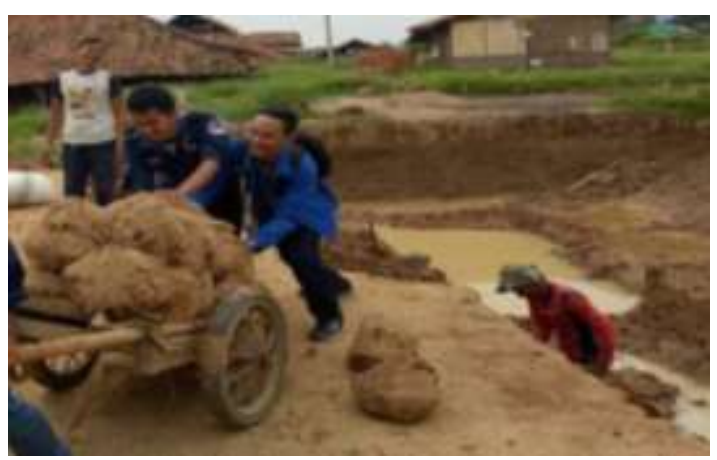

Gambar 3. Bekas Galian Material Batu Bata Merah 
Pelatihan dilaksanakan pada tanggal 20 Februari 2020 dengan menggunakan metode penyampaian atau presentasi secara langsung oleh nara sumber dari Dinas Perikanan Kab. Karawang dan diikuti dengan sesi tanya jawab dan diskusi, kemudian para peserta diperkenankan melakukan magang pada unit usaha pembesaran ikan air tawar dengan teknologi keramba jaring apung di kawasan bendungan walahar selama 2 minggu. Tempat pelaksanaan pelatihan adalah di Balai Desa Mekarmulya dengan susunan acara : Pembukaan, Pembacaan ayat Suci Al-Quran, Sambutan Pihak Teknik Industri UBP Karawang, Sambutan Kepala Desa Mekarmulya, Materi dari Narasumber dari Dinas Perikanan Kab. Karawang, Materi dari Teknik Industri UBP Karawang kaitannya bagaimana meningkatkan efisiensi produksi dan Keselamatan dan Kesehatan Kerja produksi batu bata merah, diskusi, doa dan penutup. Tercatat peserta yang hadir sebanyak 32 orang pengrajin bata merah dan 5 orang perangkat desa. Kegiatan ini dibantu juga oleh mahasiswa Teknik Industri yang berjumlah 7 orang. Materi yang disampaikan diantaranya adalah mengenal macam-macam ikan air tawar sebagai ikan budidaya seperti ikan lele, ikan nila, ikan mujaer, ikan mas, dan lain-lain, teknik pembibitan, teknik pembesaran ikan, teknik pembuatan pakan secara mandiri, dan teknik pengolahan dan pemasaran ikan.

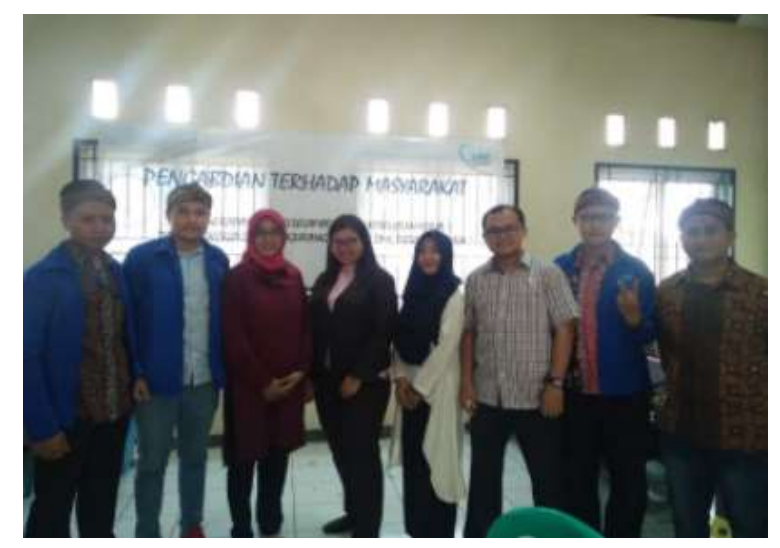

Gambar 4. Kegiatan Pengabdian kepada Masyarakat Desa Mekarmulya 


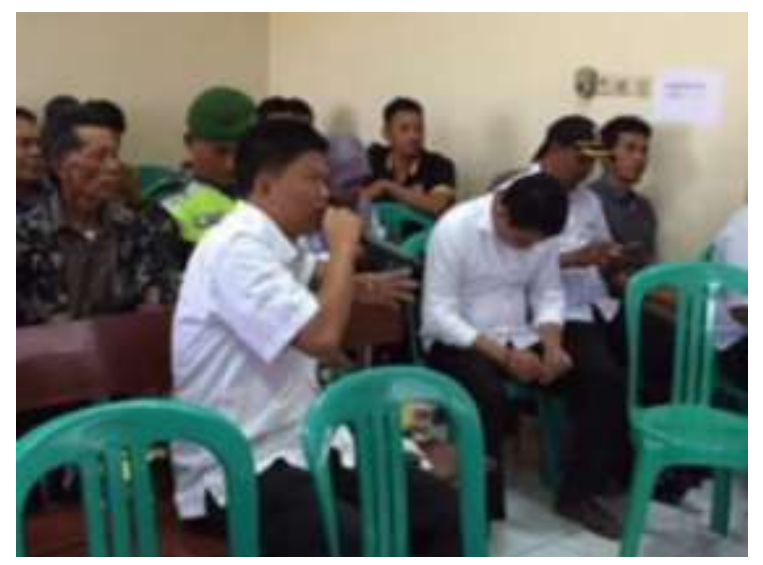

Hasil pelatihan selanjutnya ditindaklanjuti dengan melakukan monitoring dan evaluasi yang berkelanjutan bersama dengan perangkat Desa Mekarmulya sehingga kegiatan pelatihan ini benar-benar memiliki nilai manfaat yang dapat dirasakan masyarakat. Selain pelatihan budidaya ikan, para pengrajin bata merah juga diberikan pelatihan proses produksi pembuatan batu bata merah, dalam konteks bagaimana meningkatkan efisiensi produksi agar industri batu bata merah bisa bersaing dengan bata ringan (hebel) dipasar dan kaitan dengan keselamatan dan kesehatan kerja pada proses pembuatan batu bata merah, dan bagaimana menciptakan sistem kerja yang ergonomis sehingga proses kerja yang serba mengandalkan kerja fisik ini aman dan tidak menimbulkan cedera otot rangka, minimal mampu mengurangi keluhankeluhan otot rangka akibat pembebanan kerja fisik yang terus menerus.

\section{HASIL DAN PEMBAHASAN}

Kegiatan pengabdian kepada masyarakat ini memberikan hasil sebagai berikut:

1. Terdapat peluang bagi para pengrajin batu bata merah untuk mendapatkan tambahan pendapatan yaitu dengan memanfaatkan lobang/kobakan bekas galian material tanah sebagai bahan baku bata merah. Hasil observasi langsung menunjukkan bahwa rata-rata luas bekas galian tanah yang terbentuk adalah 4 meter x 6 meter dengan kedalaman ratarata 2 meter. Volume demikian mampu menampung ikan lebih dari seribu ikan air tawar khususnya ikan nila yang memang membutuhkan ruang yang lebih lebar. Jumlahnya bisa lebih besar untuk jenis ikan tawar yang lain (sumber : medanbisnisdaily.com).

2. Pada saat pemaparan tentang budi daya ikan air tawar dari Dinas Perikanan Kabupaten Karawang, para peserta terlihat antusias dan mendengarkan dengan seksama. Beberapa poin penting yang disampaikan nara sumber adalah kunci dari kesuksesan budidaya ikan 
air tawar diantaranya pemilihan bibit yang unggul dapat dilihat dari ciri fisiknya paling mudah adalah bibit tersebut aktif bergerak, selanjutnya pemilihan pakan terbaik yang banyak mengandung nutrisi terutama karbohidrat/lemak (70\%) dan protein (30\%) lebih bagus lagi jika dicampur dengan probiotik dan vitamin (sumber: bulelengkab.go.id). Pakan alternatif dapat juga diberikan untuk mengurangi biaya budidaya misalnya dengan diberikan dedak ataupun limbah sisa makanan. Kunci kesuksesan yang lain adalah memperhatikan lingkungan diantaranya adalah pengontrolan suhu air, kebersihan kolam dari tanaman penganggu dan juga dari hewan pengganggu seperti ular dan yuyu. Disamping itu pula, hal yang penting diperhatikan juga adalah sirkulasi air. Air dengan sirkulasi yang bagus akan memberikan efek yang baik bagi kesehatan ikan.

3. Para pemateri juga menjelaskan bagaimana cara pengolahan daging ikan menjadi beberapa makanan olahan seperti nugget ikan, ikan asin, ikan asap, dan lain-lain.

4. Tindak lanjut dari kegiatan pengabdian kepada masyarakat ini adalah pendampingan dari Dinas Perikanan Kab. Karawang bekerja sama dengan Teknik Industri UBP Karawang kepada para peserta pengrajin batu bata merah dalam budidaya ikan air tawar. Untuk mempermudah koordinasi, dibentuk kelompok budidaya ikan air tawar. Terdapat 6 kelompok yang terbentuk dan masing-masing kelompok langsung melakukan pembibitan. Ikan air tawar yang dipilih untuk dibudidayakan adalah ikan nila karena merupakan ikan yang mudah beradaptasi dengan lingkungan (sumber: kkp.go.id).

5. Disamping pelatihan budidaya ikan air tawar, para peserta juga diberikan sosialisasi mengenai keselamatan dan kesehatan kerja dalam proses pembuatan bata merah. Proses yang diidentifikasi memberikan cedera otot adalah mencangkul dan mengangkat material tanah dari galian ke atas karena masih dilakukan secara manual. Oleh karena itu para pekerja diminta untuk berhati-hati dan memperhatikan asupan cairan serta cukup istirahat.

\section{KESIMPULAN DAN SARAN}

Kesimpulan yang dapat diambil dari kegiatan pengabdian kepada masyarakat ini adalah bahwa terdapat potensi bekas galian material batu bata merah menjadi kolam untuk budi daya ikan air tawar sebagai tambahan penghasilan bagi para pengrajin bata merah yang mulai menurun. Untuk sementara waktu, sebagai permulaan ikan yang direkomendasikan adalah ikan nila karena mudah beradaptasi dengan lingkungan dan cepat berkembang biak. Selain budi daya 
ikan dan dijual secara mentah, juga disarankan untuk menjual hasil ikan tersebut berupa makanan olahannya seperti nugget, ikan asap, dan lain-lain.

Sebagai tindak lanjut, disarankan kepada Dinas Perikanan Kab. Karawang dan Teknik Industri UBP Karawang untuk senantiasa melakukan pendampingan sampai dengan pemasaran hasil ikan mentahnya dan produk hasil olahannya.

\section{DAFTAR PUSTAKA}

www.karawangkab.go.id diakses pada 03 Maret 2020

https://kkp.go.id/djpb/bbpbatsukabumi/artikel/15068-kelebihan-ikan-nila diakses pada 03 Maret 2020

https://food.detik.com/info-kuliner/d-4793344/hari-ikan-nasional-ini-5-ikan-air-tawarindonesia-yang-populer diakses pada 03 Maret 2020

https://bulelengkab.go.id/detail/artikel/cara-budidaya-ikan-nila-di-kolam-kecil-tapi-untungbesar-48 diakses pada 03 Maret 2020

https://www.medanbisnisdaily.com/news/read/2018/05/14/347008/kolam_ideal_untuk_budid aya_nila/ diakses pada 03 Maret 2020 